\title{
How to Attract Millennials? Indonesian Sharia Banking Opportunities
}

\author{
MUAMMAR BAKRY \\ Syariah and Islamic Law \\ Universitas Islam Negeri (UIN) Alauddin \\ Makassar \\ INDONESIA
}

\author{
RAHMAN AMBO MASSE \\ Islamic Economics and Business \\ IAIN Parepare \\ Parepare \\ INDONESIA
}

LUKMAN ARAKE

Syariah and Islamic Law

IAIN Bone

Bone

INDONESIA

\author{
MUHAMMAD MAJDY AMIRUDDIN \\ Islamic Economics and Business \\ IAIN Parepare \\ Parepare \\ INDONESIA
}

\author{
ABDUL SYATAR \\ Syariah and Islamic Law \\ Universitas Islam Negeri (UIN) Alauddin \\ Makassar \\ INDONESIA
}

\begin{abstract}
Age is often one of the factors determining the target market of a business. By knowing the potential customer's age, we determine what kind of marketing strategy should be proposed. Along with the times, many business people are eyeing millennials because of their consumptive lifestyle. It is not surprising that millenials have now dominated consumer databases. The facts have not skipped the attention of the sharia banking sector in Indonesia. This study aims to construct the opportunity for Bank Syariah Indonesia to grasp millennials as a market share. This study uses field research with qualitative methods, carried out by descriptive analysis. The data sourced from interviews and questionnaires. Islamic banks' opportunities to attract millennials include
\end{abstract}


familiarity with Islamic banking products and contracts, momentum of Hijrah, digitizing Islamic banking, and unique segmentation. These opportunities can be taken into consideration in expanding the Islamic banking market in Indonesia.

Key-Words: -Islamic Banking, Digital, Millenial, Marketing, Business, Islamic Law

Received: July 15, 2020. Revised: December 19, 2020. Accepted: January 12, 2021.

Published: January 26, 2021.

\section{Introduction}

Sociologically, bank regulation is based on the profit-sharing principle as an intermediary system integrated with the national banking system. Islamic banks are an alternative bank based on Islamic values following the beliefs of some Indonesians [1]. Sociologically-empirically, the actualization of Islamic values in the economic and financial fields is an accommodative form of thinking that Islamic teachings can be implemented in Indonesia through the internalization of Islamic values in society's sociological life [2], not through the formalization of teachings in the form of establishing an Islamic state [3]. On the other hand, some Indonesian people think Islamic teachings can only be actualized systematically and institutionalized if formalized through an institution covered by statutory regulations [4].

In 2020, there were 14 Islamic commercial banks and 26 commercial bank units that opened sharia units and 160 BPRS banks, bringing the total network of Islamic banking offices to 2,496 offices [5].

Sociological experts map the millennial generation as a generation born between the period 1980-2000. This definition comes from Millennial, which was first coined by William Strauss and Neil in their book entitled Millennials Rising: The Next Great Generation. The term millennial was invented in 1987 after assuming that the generation born in 1982 would be connected to the millennial era when entering high school education [12]. After that, the term millennial was studied and examined in various theories. The conclusion is that the millennial generation is the generation born in the 1980-2000 period.

The researchers generally set the birth age standard to determine the Millennial generation from various definitions related to the Millennial generation. Moreover, they generally agreed on the time range 1980-2000. So, individuals born in the 1980-2000 period are termed the Millennial generation. 2020 is a marker of a change in the demographic structure of Indonesia's population. The 2017 Millennial generation population has reached 88 million people or 33.75 percent of Indonesia's total population [6]. Meanwhile, 2020 is the peak of the Millennial generation's productivity. The average age of the Millennial generation has reached the age of 20 to 40 years.

The IDN Research Institute divides the Millennial generation based on age categories into two groups, first, junior Millennial, namely the generation born in 1991-1998. Second, Senior Millennials, namely the generation who were born in 1983-1999. Millennial population by age. Millennials aged 20-35 years reach 24 percent or around 63.4 million of the total population of productive age, reaching 179 million in 2019 [7].

Map of the Millennial generation's distribution based on residence area, there are around 55 percent living and living in urban areas. The shift in housing patterns from rural communities to urban communities implies changing mindsets, culture, social values, and behavior. The tendency to think in urban communities is a more open and multicultural social life.

Indonesia is projected to enter the demographic bonus for the period 2020-2035. The demographic bonus is characterized by a significant increase in the population of productive age. In 2020, the productive age population will reach 183.5 million out of Indonesia's 271 million population. One generation group whose productive population has increased sharply is the Millennial community. Data shows that in 2020 the productive millennial population will reach $46 \%$ or around 86 million 
people of the Indonesian population's total productive age population [6].

In 2016, the Financial Services Authority released data on e-banking services users, including internet banking, mobile banking, SMS banking, and phone banking, reaching 50.5 million users. Meanwhile, the utilization of transactions using ebanking facilities reached 405 million transactions. It is supported by the ownership of digital devices in the form of smartphones (43\%). While the e-commerce market grew by around $20.7 \%$, the online shopping level reached $13.4 \%$, with total revenue reaching 5.6 billion dollars in 2016 [8].

IDN Research Institute data shows that Millennials are very familiar with financial products. There are numbers that $80.2 \%$ have savings products at conventional banks; $19.3 \%$ use health insurance products. Meanwhile, Islamic banks, including Islamic banks, comprise only around $1.7 \%$ of the Millennial population throughout Indonesia. Especially for Hajj savings products, it reaches $0.3 \%$ of the total Millennial Muslims nationally [7].

The 2016 OJK survey shows that the level of financial literacy in Indonesia only reaches $29.7 \%$. This figure is far below other ASEAN countries, such as Malaysia, around $66 \%$, Thailand $73 \%$, and Singapore, around $98 \%$. The lack of knowledge of financial transactions has an impact on decision making that leads to economic prosperity. Therefore, wrong decision-making results in financial management behavior that is vulnerable to financial crises and fraudulent investment [9]. Also, investment decisions based on rational considerations will be less risky rather than emotional decisions. In 2018 the OJK released consumer losses due to investment fraud and investment decisions based on emotional considerations of up to IDR 100 trillion over the past decade [10]

Digital banking transformation is getting stronger after the outbreak of the Covid 19 worldwide, including Islamic banking. Maintaining distance and reducing activities outside the home forces the banking industry to digitize services. Besides, market changes and customer needs are the reasons for this digitization. However, digital banking targets services oriented towards customer needs and market penetration to reach a wider market share in the most cost-efficient way [11]. This reseach construct opportunitis for sharia banking tp garsp millennial attention.

\section{Literature Review}

According to Manheim, generation is a social construction where a social group has the same age, perspective, and background. A generation group comprises individuals with the same birth year background within 20 years with the same social and historical factors [12]

Meanwhile, according to Kupperschmidt, generation is a group of individuals that can be identified based on the similarity of birth year, age, location, and social factors in the individual's life. It has a significant influence on its growth cycle [12].

The millennial generation is a generation born in the ratio of 1980 to 2000. Millennial Generation is also referred to as generation Y. This term became known and used in the editorial of major United States newspapers in August 1993 [12].

According to Stafford and Griffis (2008), the Millennial generation comprises a population born in the 1980s to 2000s. Meanwhile, according to the United States Census Bureau (2015), the Millennial generation is born between 1982 and 2000 [12]. Millennial is a generation born between 1977 and 1998, familiar with technology, happy to work, and curious [13]

In general, every 20 years, there is a group of generations who have different perspectives, social situations, and backgrounds. Before the emergence of the Millennial generation, generation $\mathrm{X}$ was identified as being born between 1960 and 1980. This generation is characterized by challenges to risk and has careful consideration in decision making. This generation is influenced by the previous generation of nurturing systems, namely generations Baby Boomers [14].

Meanwhile, the generation born between 1946 and 1960 was the baby boomer generation. This generation is recognized as being born at the end of the second world war so that various aspects of social life need to be reorganized. In the era of the second world war, the birth rate of babies was quite significant, so that the generation born at that time was called the Baby Boom generation [14].

Data from the Central Bureau of Statistics estimate that Indonesia's Millennial population in 
2015 reached 33 percent of Indonesia's total population or reached 83 million people. This figure will continue to grow along with the peak demographic bonus in 2020-2030. In 2020 the productive population will reach 183.5 million people. While the Millennial generation aged 20-40 years or productive age will reach 36 percent of the total population of Indonesia, or reach 86 million people [6].

The advantages possessed are resilience, creative, dynamic, familiar with technology and social media, and comfortable to resign from a job.

According to Gallup, the characteristics of the millennial generation include:

1. Millennials work to receive a salary and pursue a goal (something that has been previously mentioned).

2. Milennials are not really after job satisfaction, but what Millennials want more is the possibility of developing themselves in that job (learning new things, new skills, new perspectives, getting to know more people, taking opportunities to develop, and likes)

3. Millennials do not want bossy and controlling bosses

4. Millennials do not want an annual review; Millennials want an ongoing conversation

5. Millennials do not think to improve their weaknesses; millennials think more about developing their strengths.

6. For millennials, work is not just working, but work is part of their life [12]

The millennial cluster can be mapped into two clusters: the urban millennial cluster and the rural millennial cluster. The urban millennial generation has different characteristics from the rural millennial generation. The urban millennial generation has three main characteristics: first, high self-confidence, their character has confidence in their potential (selfconfidence), free to express opinions. Second, creativity-dynamic, character, rich in ideas, think contextually (out of the box), and think pragmatically and realistically. Third, socialites, their characters like to socialize and actively access the internet and social media [12].

Sharia Banking utilizes online banking services to expand the sharia service unit (office channeling) at branch offices. This service is a standard of service and, at the same time, a promotional media for Islamic bank products in city districts. The benefits of using digital services consist of: First, digital technology can synergize connectivity between banks, employees, and customers regarding financial transactions and financing services. Second, the digital-based data management process is more efficient, and connectivity validated through the Indonesian bank database, thereby accelerating decision making. Third, direct automation of processes, leading to paperless use. Fourth, product innovation, service, and marketing strategies are broader in reach [15].

\section{Research Methodology}

This study's writing is based on field research with qualitative methods, carried out by descriptive analysis. The data in this writing comes from interviews and questionnaires. Interview informants consisted of practitioners at the Makassar branch of BNI Syariah, Bank Muamalat Makassar staff, State Civil Apparatus (ASN) from lecturers, students, and the general public. The data was obtained through direct interviews with the sources. In addition to faceto-face interviews, data were obtained by distributing questionnaires online through the warship group. This study uses only one data validity testing model, namely the internal validity or credibility tests. The data credibility test used was observation extension, persistence improvement, and source triangulation. Interviews were conducted several times and verified by source triangulation models to assess data validity. The triangulated data is then outlined in the research results to be further mated with secondary sources in books, journals, DSN-MUI fatwas, and applicable laws and regulations to expand the discussion's study.

\section{Results}

\subsection{Millenial Perception towards Sharia}

\section{Banking}

In addition to literacy and education strategies, Islamic banks in the city of Makassar also have collaborations or MoUs with campuses for educational programs on Islamic banking basics that aim to attract customers. Cooperation 
fields include payroll or employee salaries and offering capital assistance to cooperatives with a channeling system. Such as the MoU on the UIN Alauddin Makassar campus with the Makassar branch of BNI Syariah [16].

The results of this interview were strengthened by the google form questionnaire, which was circulated via Whatsapp. The distribution of this questionnaire is targeting students and civil servants in the city of Makassar. The results of the questionnaire that were successfully answered were 94 respondents. As many as $62.8 \%$ are aware of the existence of Islamic banks. $7.4 \%$ do not know, $27.7 \%$ do not know, and $2.1 \%$ are doubtful.

\subsection{Sharia Digital Banking}

The services provided by Islamic banks include manual services, where customers and prospective customers come to the Islamic bank office to open accounts, apply for financing, and conduct financial service transactions. b) Digital services, namely Islamic banks, provide digital services through internet applications according to each Islamic bank's website. The website contents are a selection of financial transaction features, such as mobile banking and internet banking. Apart from using internet applications, Islamic banks also provide services through social media, such as Facebook, Instagram, and WhatsApp. However, services through social media are information services and the formation of particular community groups. To respond to specific segments, Islamic banks carry out strategies such as Islamic business. This Islamic business program includes savings products targeting the education segment, Islamic campuses, Islamic boarding schools, and Islamic schools. Especially for Millennials, regular savings products are offered for students and savings plans for Millennials who are productive or working, aged 25-40 years. This product can be accessed via offline and online media [17].

Islamic bank statistics for June 2020, nationally there are $27,918,794$ third party funds distributed to 238,768 giro wadi'ah products, and wadi'ah savings of $16,370,028$ customers, a total of $16,608,796$ wadi'ah customers. There are 57,665 nonprofit sharing current accounts, 10,929,808 regular savings products, and 322,525-time deposit products [5].

Sharia bank digital banking program consists of funding products, namely savings, current accounts, and time deposits; Financing products, namely Home credit, pension financing, multi-use financing and Service products, namely debit card ownership and investment products in the form of ownership of Sukuk or shares. Each product's digital features are equipped with product details, opening requirements, benefits, and tariffs. However, the contract's explanation and the contract's characteristics are not clear on the product detail features. Thus, in displaying Islamic banking digital services' main features, there are no features related to education and literacy [18].

Data from questionnaires were distributed online in various Whatsapp groups. Ninety-four respondents gave different answers related to perceptions about Islamic bank products that suit Millennial tastes. $63.8 \%$ of respondents answered that it is easy to access via digital. $25.5 \%$ of respondents answered firmly and did not confuse. $38.3 \%$ of respondents answered easy and cheap services. $4.3 \%$ of respondents answered difficultly but following beliefs.

Respondents' responses regarding digital features should be available on digital banking services. Respondents' answers include (1) Mobile Banking Features. (2) Capital Features. (3) ATM features. (4) Sharia Investment Features. (5) Halal Product Features and Right on Target.

Millennial Muslim communities often use Islamic bank digital banking. Digital banking features, Muamalat bank consists of Muamalat Din, Muamalat Mobile Banking, Muamalat Internet Banking, Muamalat ATMs, and Muamalat outlets. These features can be downloaded on the https://www.bankmuamalat.co.id/e-banking page. These features facilitate customers for transfers, payments, Go-Pay, To Up, and online debit shopping with Muamalat bank cooperative merchants. However, the transfer menu is not yet able to serve all banks, only for a few banks" [19].

Meanwhile, Bank BNI Syariah has digital banking products with features, ATM, SMS Banking, Internet Banking, Tap cash IB Hasanah, Mobile Banking, Phone Banking, Mobile Services, 
HasanahKu BNI Syariah, and Hasanah Mobile. These features can be accessed on the https://www.bnisyariah.co.id/id-id/ebanking page. These features also facilitate customers for online transfers, payments, Top Up, Go-Pay, and online debit shopping with BNI Syariah bank merchants [20].

Islamic banks' strategic steps are related to education and literacy programs, namely training workshops related to Islamic banking basics aimed at students exploring contracts and sharia banking management governance. The educational program accepts participants from schools, mass organizations, majelis taklim, and students to learn akad and Islamic banking. Meanwhile, workshops, namely literacy programs in the form of classes. So, this program is aimed at groups of people who want to explore the basics of Islamic banking. The learning is equipped with the material. usually, 1 class consists of 20 people "[17].

One of the features that the Millennial Muslim community hopes for is the educational and literacy features. This feature is essential because people generally do not understand and understand Islamic bank contract terms. For that, we need features that educate the public regarding Islamic bank contracts. Islamic banks have provided a mobile banking application. The available features include financial transaction service features, but the education and literacy features are still not evenly distributed [22] to facilitate literacy and education of Islamic bank contracts, literacy and education features are needed relating to the term Islamic bank contract. The content of features can be in the form of a narrative or video [23]. In this digital era, everything can be accessed easily through gadgets; therefore, Islamic banks can provide educational service features and contract literacy [21].

Based on the interview above, generally, the Millennial Muslim community expects educational and literacy features to explain the Islamic bank product contract. Generally, ordinary people do not understand and understand the term contract. The term sharia bank contract was adopted from fiqh muamalah. The content or feature content can be in the form of videos and narrations. Several Islamic banks that launched digital banking applications, Bank BNI Syariah and Bank Muamalat, have prepared educational and literacy features with video content and narrative form. This feature can be accessed via the https://www.bankmuamalat.co.id/seputar-ayo-hijrah for Muamalat bank https://www.bnisyariah.co.id/idid/infolain/edukasiperentuksyariah for banks BNI Syariah. The contract's explanation is packaged in the form of a video, making it easier for the Millennial Muslim community to understand the Islamic bank contract's terms in detail.

Millennial Muslim communities often use Islamic bank digital banking. Digital banking features, Muamalat bank consists of Muamalat Din, Muamalat Mobile Banking, Muamalat Internet Banking, Muamalat ATMs, and Muamalat outlets. These features can be downloaded on the https://www.bankmuamalat.co.id/e-banking page. These features facilitate customers for transfers, payments, Go-Pay, To Up, and online debit shopping with Muamalat bank cooperative merchants [19]. Meanwhile, Bank BNI Syariah has digital banking products with features, ATM, SMS Banking. Internet Banking, Tap cash IB Hasanah, Mobile Banking, Phone Banking, Mobile Services, HasanahKu BNI Syariah, and Hasanah Mobile. These features can be accessed on the https://www.bnisyariah.co.id/idid/ebanking page. These features also facilitate customers' online transfers, payments, Top Up, GoPay, and online debit shopping with BNI Syariah bank merchants [20].

Based on the interview above, Millennial Muslim communities take advantage of the facilities of Islamic bank products. Digital banking facilities are used for the benefit of financial transactions. The Covid 19 pandemic period, which requires people to keep their distance and not touch their hands, impacts increasing digital banking use. Millennials often use online transfers and payments via smartphones [18].

\section{Sharia Banking Proposed Opportunities}

\subsection{Products and Contracts Familiarities}

Based on interview data, it shows that the Millennial group is interested in saving or taking financing at Islamic banks due to factors, (1) Avoiding usury, (2) Management of syar'I and halal funds, (3) Carrying out religious teachings, (4) 
Guaranteed funds by guarantee institutions savings, (5) Free of deductions and admin fees. Before field socialization, marketing funding conducts customer mapping, determines target market share, and provides insight into prospective customers regarding Islamic bank funding products [24]

Millennial perceptions regarding the implementation of sharia principles in Islamic banks' agreement and financial management are perfect. Millennial believes that Islamic banks' operational systems and financial transactions are free of usury, gharar, maisir, zalim, and haram. Therefore, the interest in becoming a customer of a sharia bank is due to financial constraints and free admin fees and deductions. Quantitatively, $74.5 \%$ of respondents think that Islamic bank products are following sharia principles.

The 2016 OJK survey shows that the level of financial literacy in Indonesia only reaches $29.7 \%$. This figure is far below other ASEAN countries, such as Malaysia, around $66 \%$, Thailand $73 \%$, and Singapore, around $98 \%$. The lack of knowledge of financial transactions has an impact on decision making that leads to economic prosperity. Therefore, wrong decision-making results in financial management behavior that is vulnerable to financial crises and fraudulent investment [9].

The completeness of literacy and educational features of the basics of Islamic banking is the hope of Millennials. These features can be in the form of narrative content in explanations related to Islamic bank product contracts. In addition to narrative content, video content is also needed in the form of a necessary explanation of the Islamic bank product contract. Bank Muamalat and BNI Syariah bank have literacy and education features packaged in narrative and video form, making it easier for Millennials to know the Islamic bank product contract's terms and characteristics. Knowledge of basic financial concepts and Islamic finance affects implementing sound financial behavior, such as managing financial behavior, saving, and consistent behavior in paying monthly bills.

\section{2 Momentum of Hijrah}

Interestingly Millennials are also interested in muamalah studies. There are around $54.6 \%$ of respondents who follow and explore this study [25]
Since 2017, the hijrah community's trend has been formed, spearheaded by the artist Hanan Attaki by forming the hijrah community for the first time in Bandung. Since then, the hijrah community has begun to penetrate the country and form communities in big cities in Indonesia. Generally, the hijrah community consists of Millennial Muslims looking for self-identity and Islamic understanding and even claim to migrate to understand a more authentic Islam. 2018 is the largest hijrah community meeting held at the Jakarta Convention Center, which various national artists and migrant communities attended from various regions [26]. Islamic banks in Indonesia utilize the moment of the hijrah community's presence by presenting products and services according to the tastes of this migrating community.

The dynamics of the hijrah community and the religious studies it has developed show that Islamic understanding does not only touch the issue of ritual worship alone, but Islamic studies want to be understood as a whole and integrally. The high interest of Millennials in muamalah studies should transpire responded to well by Islamic banks. One of the implementations of muamalah theories is carried out in Islamic banks.

\subsection{Digital Banking Facilities}

The population of Internet access service users among Millennials in 2016 reached 72.2 percent or 59.9 million people. This data shows that Millennials are familiar with cyberspace and make internet access a basic need in everyday life [6]. Meanwhile, smartphone users in Indonesia reached $94 \%$ of the total population aged 16-64 years. The average time spent surfing the internet is about 7 hours per day. About 33\% of internet access is allocated for APPS banking activities [27].

Alvara Research's research results show that digital banking services, such as SMS banking services performed by younger millennials, are around $10.5 \%$, while senior Millennials are around $11.7 \%$. Mobile banking service users for younger Millennials are around $9.0 \%$, while senior Millennials are around $9.1 \%$, and internet banking service users for Millennial juniors are around 8.7\%, while Millennial seniors are around $7.0 \%$. As for ownership of financial products, Millennial juniors are around $85.4 \%$, while Millennial seniors are 
around $85.2 \%$ [25]. The research results confirm this research by Jennifer Brodmann et al., who concluded that the Millennial generation generally uses car banking for banking services because it is easy to access via smartphones [28].

Generally, the millennial generation takes advantage of online banking transactions to pay bills and transfer payments related to online businesses. Thus, banking includes payment and transfer features that make it easy and a vast network of partners. Besides, millennials are an unstable generation in the financial sector and are wasteful in financial management. Therefore, banks provide financial education and literacy features to guide the millennial generation to get caught up in waste and fake investment [29].

Alvara Research released data related to the use of digital banking services among Millennials. For the needs of SMS Banking for Millennial juniors around $10.5 \%$ and Millennial seniors, around $11.7 \%$. The use of mobile banking services for Millennial juniors is around $9.0 \%$ and $9.1 \%$ for Millennial seniors. Meanwhile, internet banking service usage is around $8.7 \%$ for Millennial juniors, and Millennial seniors, around $7 \%$. The need for e-channel financial products consisting of mobile banking, SMS banking, and internet banking among Millennials is very high. Moreover, this e-channel product can easily be accessed through the play store application using gadgets, smartphones, and the internet, which, of course, is a Millennial habit [25].

Islamic banks must prepare a strategy in facing the Millennial era with this trend of e-channel transaction services. The strategy includes 1) adjusting information technology. 2) Planning a new business model. 3) Implementation of new business models. 4) Risk management. 5) Internal supervision.

The internet era creates opportunities for information intake from various directions so that banks can utilize information symmetrically, and customers can access information transparently and in real-time. Information disclosure makes Islamic banks more stringent in supervision because they must disclose information transparently regarding compliance with sharia principles in their transaction system [30].

The Digital Islamic Economy has a potential market share, such as the education industry, halal food, Muslim fashion, halal tourism, pharmaceuticals, and halal cosmetics, as well as the Islamic financial market. The business sector can be packaged in the form of e-commerce retailers, marketplaces, and economic sharing. Muslims are very strategic e-commerce consumers. The transaction value reached USD 107 billion in 2014 [31].

The habit of living in new normal activities requires intense pressure and top-down pressure. Various regulations were issued to force people to limit themselves from activities outside the home and avoid crowds. The Large-Scale Social Restriction Regulation (PSBB) and Regional Government Regulations Related to the Use of Masks are topdown pressures that limit social activities. This process will gradually be accepted as a habit. Therefore, the trading and transaction system will also change diametrically. Conventional business and transactions are slowly shifting to online trading and transactions based on digital banking. For this reason, Islamic banks must also technologically improve in order to meet the transaction needs of their customers.

In 2020, 13 Islamic technology financials are operating in Indonesia and registered with the Financial Services Authority, including 1) Sharia Fund, 2) Sharia Investree, 3) Kapital Boots, 4) Ethics Crowd, 5) Alami, 6) Amana. This company distributes around 1 trillion fresh funds.

Regulations are governing the licensing of this sharia fintech company, namely, Bank Indonesia Regulation (PBI) Number 19 of 2017 concerning the Implementation of Financial Technology, PBI No. 20 of 2018 concerning Electronic Money, POJK No. 12 of 2018 concerning Digital Banking, POJK No. 13 of 2018 concerning Digital Financial Innovation, Fatwa DSN-MUI No. 117 of 2018 concerning TechnologyBased Financing Services Based on Sharia Principles, and DSN-MUI fatwa No. 116 of 2017 concerning Sharia Electronic Money.Expectations can be affected due to individual needs, namely all the basic needs that a person feels to reach their welfare and expectations, or explicit service promises, namely explicit service promises, as stated in brochures or advertisements. Millennial Muslims find it difficult to understand the Islamic bank product contract. Although the Islamic bank product 
contract is contained in brochures and agreements, generally, Muslim millennials do not correctly understand these contracts' terms. Therefore, it allows Millennials to understand the terms of Islamic bank product contracts more deeply through literacy and educational features.

\subsection{Unique Segmentation}

The acceptance of the Millennial Muslim community of products, the practice of sharia principles, and Islamic banking services have received various responses. In general, Millennial Muslims are familiar with Islamic bank products, including funding, financing, and services. Millennial Muslims in Makassar who choose the Ayo Hijrah Savings product are around $24.5 \%$ of the respondents. $29.8 \%$ of respondents chose a savings product with the Muamalat Din application. While $38.3 \%$ of respondents chose HasanahKu products. $3.2 \%$ of respondents chose the Tunjuk Rumah product. Moreover, $1.1 \%$ of respondents answered Islamic savings. It shows that Millennials well know Islamic bank products.

Meanwhile, acceptance is related to the practice of sharia principles due to religious, emotional factors. Generally, Millennial Muslims become customers of Islamic banks due to religious, emotional factors, namely avoiding usury, practicing religious teachings, and managing halal funds. However, some Millennials choose Islamic banks because of pragmatic considerations, namely financial transactions free of admin fees and free deductions. Millennial assumes that the financial transaction system in Islamic banks follows Millennial Muslims' personality, namely $31.9 \%$ of respondents answered very accordingly. $56.4 \%$ of respondents answered accordingly. If the respondent who answers is very suitable, combined with the respondent, answers accordingly, then there is a figure of $88.3 \%$ of Millennial Muslims who think that the Islamic bank financial transaction system is following Millennial Muslims' personality.

Millennial Muslim communities feel the friendly and warm services of Islamic banks. Customers are served by all levers, regardless of their lea or subordinates. They are competing to greet and offer assistance while in the Islamic bank office.
While digital banking services and mobile banking application features, several services still do not address customers' financial transaction needs. Digital banking features still need to be improved in Islamic bank cooperation partners in the transfer process for online shopping. Besides, there is still a need to add merchants as shopping partners by utilizing Islamic bank debit card facilities. The mobile banking application needs to be upgraded according to the tastes of customers' financial transaction needs. Mobile banking applications are sometimes difficult to use and often an error even though Millennials' need for online transactions is very high.

\section{Conclusion}

The digitalization of Islamic banking has an opportunity to gain market share for the Millennial Muslim community include adequate understanding of Sharia Banking Products, the digitalization of Islamic bank products features Millennial tastes, unigue segmentation and momentum of Hijrah. Specificly, the digitization of Islamic banking is oriented towards efficiency and transparency, which can be accessed in real-time. Meanwhile, the challenges are strict supervision of consistency in applying Sharia principles and physical meetings. Even though virtual world transactions still require manual follow-up.

\section{References}

[1] Tutik, T. T. (2016). Kedudukan Hukum Perbankan Syariah dalam Sistem Perbankan Nasional. Muqtasid: Jurnal Ekonomi Dan Perbankan Syariah, 7(1), 1. https://doi.org/10.18326/muqtasid.v7i1.1-27

[2] Amalia, E. (2016). Transformasi Nilai-Nilai Ekonomi Islam Dalam Mewujudkan Keadilan Distributif Bagi Penguatan Usaha Kecil Mikro Di Indonesia. Al-Iqtishad: Journal of Islamic Economics,

[3] Amin, A. M. (2017). Formulasi Negara Islam Menurut Pandangan Para Ulama. IN RIGHT Jurnal Agama Dan Hak Azazi Manusia, 7(1), 64-80.

[4] Masse, R. A. (2015). IMPLEMENTASI PRINSIP SYARIAH DALAM AKAD PEMBIAYAAN PERBANKAN SYARIAH DI KOTA MAKASSAR (STUDI PADA BANK MUAMALAT DAN UNIT USAHA SYARIAH BANK PEMBANGUNAN DAERAH SULSELBAR). Universitas Islam Negeri Alauddin Makassar. 
[5] Otoritas Jasa Keuangan. (2020). Statistik Perbankan Syariah.

[6] Ali, H., \& Purwandi, L. (2017). Millenial Nusantara, Pahami Karakternya, Rebut Simpatinya (1st ed.). Jakarta: Gramedia Pustaka Utama.

[7] Utomo, W. P. (2019). Indonesia Millennial Report 2019. In IDN Research Institute (1st ed.). IDN Research Institute.

[8] Tampubolon, N., \& Dkk. (2015). Bijak Ber EBanking. In Bijak Ber E-Banking. Jakarta: OJK

[9] Ningtyas, M. N. (2019). Literasi Keuangan pada Generasi Milenial. Jurnal Ilmiah Bisnis Dan Ekonomi Asia, 13(1), 20-27. https://doi.org/10.32812/jibeka.v13i1.111

[10] Widyastuti, A. (2020). 3) 1,2,3). (February), 326340. https://doi.org/10.31933/DIJEMSS

[11] Zouari, G., \& Abdelhedi, M. (2020). Customer satisfaction in the digital era: evidence from Islamic banking. https://doi.org/10.21203/rs.3.rs-24909/v1

[12] Kementerian Pemberdayaan Perempuan dan Perlindungan Anak. (2018). Statistik Gender Tematik;Profil Generasi Milineal Indonesia (1st ed.). Jakarta: Kementerian Pemberdayaan Perempuan dan Perlindungan Anak

[13] Cudmore, B., \& Patton, J. (2010). The millennials and money management. Journal of Management ..., 4, $1-29$.

[14] Putra, Y. S. (2016). Theoritical Review: Teori Perbedaan Generasi. Among Makarti, 9(18), 123-134

[15] Dz., A. S. (2018). Inklusi Keuangan Perbankan Syariah Berbasis Digital-Banking: Optimalisasi dan Tantangan. Al-Amwal : Jurnal Ekonomi Dan Perbankan Syari'ah, 10(1), 63.

https://doi.org/10.24235/amwal.v10i1.2813

[16] Kamaluddin Abu Nawas, vice chancellor of UIN Alauddin Makassar (Personal communication), on 23 September 2020

[17] Kiki, Bank Muamalat Makassar employee, (Personal communication) on 15 June 2020

[18] Indriyani (Personal Coomunication, 2020)

[19] Nur Aisyah, (24), University Student, on 10 July 2020

[20] Abdullah Hodding (40), BPD Sulsel Customer, on 15 July 2020
[21] Dian Pratiwi Samad, Sharia bank customer, on 5 July 2020

[22] Fadillah (23), University Student, on 5 June 2020

[23] Tisa (23), Sharia Banking customer, on 17 July 2020

[24] Ismawati. (2019). Peran dan Strategi Marketing Funding Dalam Meningkatkan Jumlah Nasabah Penabung Pada Bank Syariah Mandiri KCP Panakukang Kota Makassar. Al-Mashrafiyah, 3(1), 70-82. https://doi.org/https://doi.org/10.24252/almashrafiyah.v3i1.7740

[25] Hasanuddin. (2020). Indonesia Gen Z and Millenial Report 2020

[26] Hasan, H. (2019). CONTEMPORARY RELIGIOUS MOVEMENT IN INDONESIA: A Study of Hijrah Festival in Jakarta in 2018. Journal of Indonesian Islam, 13(01), 15-30. https://doi.org/10.15642/JIIS.2019.13.1.230-265

[27] Mulyana, R. (2020). Digital Bank Opportunity and Challenges. Webinar Digitalisasi Sektor Perbankan Antara Peluang Dan Tantangan.

[28] Brodmann, J., Rayfield, B., Hassan, M. K., \& Thu Mai, A. (2018). Banking characteristics of millennials. Journal of Economic Cooperation and Development, 39(4), 43-73

[29] Hussain, M., \& Wong, C. (2015). The Online Banking Behavior of Generation Y. SSRN Electronic Journal. https://doi.org/10.2139/ssrn.2549898

[30] Musleh Al-Sartawi, A. M. A. (2018). Online financial disclosure, board characteristics and performance of islamic banks. Journal of Economic Cooperation and Development, 39(3), 93-114

[31] Kementerian Perencanaan Pembangunan Nasional. (2018). Masterplan Ekonomi Syariah Indonesia 20192024. Jakarta: Kementerian Perencanaan Pembangunnan Nasional

\section{Creative Commons Attribution License 4.0 (Attribution 4.0 International, CC BY 4.0)}

This article is published under the terms of the Creative Commons Attribution License 4.0 https://creativecommons.org/licenses/by/4.0/deed.en US 